\title{
Synthesis, Characterization and Biological Activities of a New 5-Chloroisatin Schiff Base and its Metal Complexes
}

\author{
RAGHAVENDRA RAO ${ }^{\mathrm{a}}$, K RAMAKRISHNA REDDY ${ }^{\mathrm{b}}$ and K. N. MAHENDRA ${ }^{\mathrm{a}}$ \\ ${ }^{a}$ Department of Chemistry, Central College Campus, Bangalore University, \\ Bangalore - 560 001, India \\ ${ }^{\mathrm{b}}$ Government Science College, Bangalore - 560 001, India \\ mahendra_kadidal@yahoo.com
}

Received 17 January 2013 / Accepted 15 February 2013

\begin{abstract}
Copper (II), cobalt (II), nickel (II) and zinc (II) complexes of 5-chloroisatin Schiff base (L) ( $\mathrm{L}=$ Schiff base derived from 5-chloroisatin and 2-methyl-4- nitro aniline) were synthesized and characterized. The authenticity of the ligand and its metal complexes had been established by micro analysis, IR, NMR, LC/MS, UV-Vis and electrical conductance measurements. The ligand acts as a bidentate in which the carbonyl oxygen and the azomethine nitrogen of 5-chloroisatin are involved in co-ordination. Square planar geometry was proposed for $\mathrm{Cu}(\mathrm{II})$ and $\mathrm{Ni}(\mathrm{II})$ complexes and tetrahedral geometry was proposed for $\mathrm{Co}$ (II) and $\mathrm{Zn}$ (II) complexes. The ligand and its metal complexes have been screened for their antibacterial activity against bacterias viz. Staphylococcus aureus and Escherichia coli etc. and antifungal activity against fungi Aspergillus niger and Aspergillus flavous etc. The activities of both the samples have shown significant and noticeable changes on complexations.
\end{abstract}

Keywords: Schiff base, Isatin, Antibacterial activity, Antifungal activity

\section{Introduction}

The isatin derivatives were found to exhibit on various applications in biological studies. Many isatin derived compounds and its effect has been studied in a variety of systems. Biological properties of isatin include a range of actions in the brain and offer protection against certain types of infections. Isatin has a range of actions such as CNS-MAO inhibition, anticonvulsant and anxiogenic activities. The 5-chloroisatin with 2-methyl-4-nitroaniline derivatives were found to exhibit interesting applications in physiological studies. Many isatin derived compounds possess a wide spectrum of medicinal properties and have been studied for activity against tuberculosis, leprosy, fungal, viral and bacterial infections ${ }^{1-4}$ etc.

Chohan et al. ${ }^{1}$ have been prepared Schiff bases using isatin with 2-aminothiozoles and its metal complexes also. It was observed that such compounds would carry medicinal properties of mainly as anticonvulsants. In the present study, we mainly deals with the synthesis and characterization of a novel Schiff base formed by the condensation of 5chloroisatin with 2-methyl-4-nitroaniline and its complexes with cobalt (II), nickel (II), copper (II) and zinc (II). Thus introducing another class of isatin incorporating metal-ligand 
antibacterials and antifungals. The ligand and their metal complexes have been characterized by IR, NMR, UV-Visible, LC/MS, molar conductance, magnetic moment and elemental analysis data.

The resulting Schiff base and its metal complexes were screened for antibacterial activity against Staphylococcus aureus, Escherichia coli, Bacillus subtilli, S. typhi and Pseudomonas aeruginosa and antifungal activity against Aspergillus niger, Aspergillus flavous and Candida Albicans by agar - well diffusion method ${ }^{5}$. The ligand and its complexes showed varied activity against more strains and their activity was enhanced respectively on coordination/chelation.

\section{Experimental}

All chemicals were purchased from sigma - Aldrich and used as such. The CHN analysis was carried out by using CHNS analyser of Elementar Vario III. IR spectra were recorded in Perkin IR spectrometer. NMR spectra were recorded on Varion FT - NMR. A mass spectrum was recorded in the LC/MS. UV-Visible spectra were recorded in UV-Visible spectrophotometer of Shimadzu Hitachi. The Melting points were determined in open capillaries and are uncorrected, and Conductance measurements were measured in Systronics conductivity meter in DMF.

\section{Preparation of the Schiff base (L)}

Schiff base ligand was prepared according to the following procedure. The ethanolic solutions of 5-chloroisatin $(0.01 \mathrm{~mol}, 1.92 \mathrm{~g})$ in $50 \mathrm{~mL}$ and 2-methyl-4-nitroaniline $(0.01 \mathrm{~mol}, 1.52 \mathrm{~g})$ in $50 \mathrm{~mL}$ were mixed and refluxed for about $1 \mathrm{~h}$. The reaction mixture was evaporated to a small volume and left to cool. The resulting Schiff base (Figure 1) ligand precipitated on cooling and then was filtered off, washed with ethanol and recrystallized from ethanol. The purity of the Schiff base ligand was monitored by TLC using eluants 1:1 ethyl acetate and petroleum ether and separated by column chromatography and molecular weight would be 315.5 with molecular formula of Schiff base $\mathrm{C}_{15} \mathrm{H}_{10} \mathrm{~N}_{3} \mathrm{O}_{3} \mathrm{Cl}[\mathrm{L}]$. The yield of Schiff base was $93 \%$.

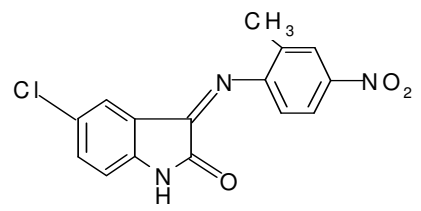

Figure 1. Schiff base (L)

\section{Preparation of complexes}

The metal complexes were prepared by adding solution of metal salts $(0.01 \mathrm{~mol})$ in $50 \mathrm{~mL}$ absolute ethanol to $100 \mathrm{~mL}$ of an ethanolic solution of the ligand $(0.01 \mathrm{~mol})(1: 1 \mathrm{ratio})$ and heating under reflux conditions for about $80-90{ }^{\circ} \mathrm{C}$ to an extent of 2 to $4 \mathrm{~h}$. Then the reaction mixture was concentrated into a small volume by evaporation method, on cooling, the metal complexes crystallizes out. The crystallized metal salts were then filtered and washed it thoroughly with ethanol and dried under vacuum over fused calcium chloride.

\section{Biological activity}

Antibacterial activity and antifungal activity measurements

The Schiff base and its complexes were screened for antibacterial activity against Staphylococcus aureus, Escherichia coli, Bacillus subtili, S. typhi and Pseudomonas aeruginosa. The antifungal activity against Aspergillus niger, Aspergillus flavous and Candida albicans by agar-well diffusion method ${ }^{5}$. 
The following strains of bacteria were used: ATCC of Staphylococcus aureus, Escherichia coli, B. subtilis, S. typhi, Pseudomonas aeruginosa and Aspergillus niger, Aspergillus flavous and Candida albicans. The both bacteria and fungi were obtained and culture maintained in Government Science College, Bangalore.

The bacterial /fungal inoculums of two to six hours containing approximately $10^{5} \mathrm{cfu} / \mathrm{mL}$ were used in these assays. The wells were dug in the media with the help of sterile metallic borer with centers at least $24 \mathrm{~mm}$. The recommended concentration $100 \mu \mathrm{L}$ of the test sample was introduced into the corresponding wells. The other wells supplemented with DMF and standard drugs served as negative and positive controls respectively, the plates were incubated immediately at $37{ }^{\circ} \mathrm{C}$ for 24 hours. Activity was determined by measuring the diameter of zones showing the complete inhibition in $\mathrm{mm}$. Gentamycin (positive control) was used as a standard drug for Antibacterial activity and Nystatin (positive control) was used for Antifungal activity. The positive controls were supplied by Government Science College, Bangalore.

\section{Results and Discussion}

All the metal complexes are colored solids and are stable towards air and have high melting points (above $200{ }^{\circ} \mathrm{C}$ ). The complexes have the general formula $\left[\mathrm{MLCl}_{2}\right]$ where $\mathrm{M}=\mathrm{Co}$ (II) $\& \mathrm{Zn}(\mathrm{II})$ and $\left[\mathrm{M} \mathrm{LCl} . \mathrm{H}_{2} \mathrm{O}\right] \mathrm{Cl}$ where $\mathrm{M}=\mathrm{Cu}(\mathrm{II}) \& \mathrm{Ni}(\mathrm{II})$.

The complexes are insoluble in water and common organic solvents but are soluble in DMF and DMSO. Hence the molecular weights could not be determined. Analytical data of the complexes suggest that the metal to ligand ratio in all the complexes is $1: 1$.

The analytical and physical data of ligand and its complexes have been described as follows.

(a) Ligand $\left(\mathrm{C}_{15} \mathrm{H}_{10} \mathrm{~N}_{3} \mathrm{O}_{3} \mathrm{Cl}\right)$ : colour: brown, yield(\%):93.0, M.P $\left({ }^{0} \mathrm{C}\right): 136$, elemental analysis (\%) calcd./found:C: $57.05 / 57.01, \mathrm{H}: \quad 3.17 / 3.14, \mathrm{~N}: \quad 13.31 / 13.29 . \quad \operatorname{IR}\left(\mathrm{cm}^{-1}\right): 3346(\mathrm{NH}$ isatin), $1718(\mathrm{C}=\mathrm{O}), 1640(\mathrm{C}=\mathrm{N}),{ }^{1} \mathrm{H} \mathrm{NMR}(\delta)$ : Isatin: 7.60(s), 7.71(d), 7.78(d) aniline: 7.81(d), 7.57(d), 7.47(d), methyl: 6.02(s), N-H: 11.06(br), UV( $\left.\mathrm{cm}^{-1}\right): 26667,37037$, mass spectra $(\mathrm{m} / \mathrm{z}): 316.5$.

(b) Complex[CuLCl. $\left.\mathrm{H}_{2} \mathrm{O}\right] \mathrm{Cl}$ : colour:brown, yield $(\%): 88.5$, M.P $\left({ }^{0} \mathrm{C}\right): 232(\mathrm{~d})$, elemental analysis (\%) calcd./found:C:38.46/37.98,H: $2.56 / 2.52, \mathrm{~N}: 8.97 / 8.85$, molar conductance $\lambda \mathrm{MS}$ $\mathrm{cm}^{2} \mathrm{~mol}^{-1}: 97$, IR $\left(\mathrm{cm}^{-1}\right):$ 3341(NH Isatin), 1703(C=O), 1620(C=N), 534(M-O), 478 $(\mathrm{M}-\mathrm{N}), 325(\mathrm{M}-\mathrm{Cl}) \quad \mathrm{UV}\left(\mathrm{cm}^{-1}\right): 25974,15873$, magnetic moment $\left(\mu_{\mathrm{eff}} \mathrm{BM}\right): 1.89$.

(c) Complex $\left[\mathrm{Co} \mathrm{LCl}_{2}\right]$ : colour: brown, yield $(\%): 89.5$, M.P $\left({ }^{0} \mathrm{C}\right): 240(\mathrm{~d})$, elemental analysis (\%) calcd./found:C:40.41/39.93, H: 2.25/2.21, N: 9.43/9.30, molar conductance $\lambda \mathrm{MS}$ $\mathrm{cm}^{2} \mathrm{~mol}^{-1}: 31, \mathrm{IR}\left(\mathrm{cm}^{-1}\right):$ 3342(NH Isatin), 1704(C=O), 1621(C=N), 535(M-O), 473(M-N), 329(M-Cl), UV $\left(\mathrm{cm}^{-1}\right): 26315,15625$, magnetic moment $\left(\mu_{\mathrm{eff}} \mathrm{BM}\right): 4.56$.

(d) Complex[NiLCl. $\left.\mathrm{H}_{2} \mathrm{O}\right] \mathrm{Cl}$ : colour: light brown, yield(\%): 85.5, M.P $\left({ }^{0} \mathrm{C}\right): 238(\mathrm{~d})$, elemental analysis (\%) calcd./found:C: 38.86/38.14,H:2.59/2.54,N: 9.07/8.98, molar conductance $\lambda \mathrm{MS}$ $\mathrm{cm}^{2} \mathrm{~mol}^{-1}:$ 63, IR( $\left.\mathrm{cm}^{-1}\right): 3348(\mathrm{NH}$ Isatin), 1701(C=O), 1623(C=N), 533(M-O), 483(M-N), 331(M-Cl), UV $\left(\mathrm{cm}^{-1}\right): 27397,14925$, magnetic moment $\left(\mu_{\text {eff }}\right.$ BM): 3.66.

(e) Complex[Zn $\left.\mathrm{LCl}_{2}\right]$ : colour: brown, yield(\%):90.5, M.P $\left({ }^{0} \mathrm{C}\right): 224(\mathrm{~d})$, elemental analysis $(\%)$ calcd./found:C: $39.83 / 39.34, \mathrm{H}: 2.21 / 2.17, \mathrm{~N}: 9.29 / 9.13$, molar conductance $\lambda \mathrm{MS} \mathrm{cm}^{2} \mathrm{~mol}^{-}$ ${ }^{1}: 33, \operatorname{IR}\left(\mathrm{cm}^{-1}\right): 3336$ (NH Isatin), 1704(C=O), 1620(C=N), 540(M-O), 485(M-N), 331(M-Cl), ${ }^{1} \mathrm{H}$ NMR(d): Isatin: 8.76(s), 7.91(d), 7.89(d) aniline: 7.90(d), 7.95(d), 7.21(d), methyl: 6.43(s) $\mathrm{N}-\mathrm{H} 12.01(\mathrm{br}), \mathrm{UV}\left(\mathrm{cm}^{-1}\right): 28011,21739$, magnetic moment: diamagnetic. 


\section{IR spectra}

The infrared absorption frequencies along with their tentative assignments for the major absorption bands pertaining to the ligand and its complexes are presented above in details. In the present investigations the tentative assignments of the infrared bands for most of the major peaks are based on the assignments of the literature value.

The IR spectrum of the free ligand is characterized mainly by the strong bands at 3346, 1718 and $1640 \mathrm{~cm}^{-1}$ which are attributed to the stretching frequencies of $\mathrm{NH}$ (aromatic), $\mathrm{C}=\mathrm{O}$ and $\mathrm{C}=\mathrm{N}$ (azomethine) groups respectively and reflected its spectral data of the metal complexes.

The IR spectra of the complexes showed a lower shift of wave numbers of both the azomethine $(v \mathrm{C}=\mathrm{N})$ and heteroatomic moieties by about $15 \mathrm{~cm}^{-1}$ respectively. The band located at the $1700 \mathrm{~cm}^{-1}$ in ligand attributed to $(\mathrm{v} \mathrm{C}=\mathrm{O})$ moiety of the isatin also moved to the lower frequency side by about $15 \mathrm{~cm}^{-1}$. For IR region was also clearly noticed that the $v \mathrm{M}-\mathrm{O}, v \mathrm{M}-\mathrm{N}$ and $v \mathrm{M}-\mathrm{Cl}$. This data on comparison with the spectra of the chelates suggests that the azomethine- $\mathrm{N}$ and Isatin-O of the ligand ${ }^{6-9}$.

\section{NMR spectra}

The protons NMR spectral data of the ligand and the $\mathrm{Zn}$ complex is presented with details. The number of protons calculated from the integration of ${ }^{1} \mathrm{H}$ NMR spectra is in accordance with that expected ${ }^{10-11}$ from $\mathrm{CHN}$ analyses results.

\section{Mass spectra}

The molecular weight 315.5 for $\mathrm{C}_{15} \mathrm{H}_{10} \mathrm{~N}_{3} \mathrm{O}_{3} \mathrm{Cl}$ and a molecular ion peak is found at 316.5 in the mass spectrum supporting the molecular formula of the ligand Schiff base.

\section{ESR spectra}

The x-band ESR spectrum of the powdered sample of the copper complex has been recorded at room temperature in solid state on $\mathrm{x}$-band at a frequency of $9.1 \mathrm{GHz}$ under the magnetic field of $3000 \mathrm{G}$. The spectral profile is typical of axial type $\left(\mathrm{g}_{11}>\mathrm{g}_{\perp}\right)$ implying $\mathrm{d}_{\mathrm{x} 2-\mathrm{y} 2}$ ground state. The $\mathrm{g}_{\mathrm{Il}}$ and $\mathrm{g}_{\perp}$ are found to be 2.28 and 2.11 respectively.

The $g_{a v}$ is related to $g_{l l}$ and $g_{\perp}$ by the equation $g_{a v}=\left(g_{I l}-2\right) /\left(g_{\perp}-2\right)$ and is calculated to be 2.5. Since the value of $g_{I I}$ is less than 2.5 then the complex possesses considerable covalent character in the metal ligand bond ${ }^{12}$.

\section{Thermogravimetric studies}

The TGA studies of the complexes were carried out in the nitrogen atmosphere at a rate of $10^{\circ}$ per minute up to $700{ }^{\circ} \mathrm{C}$. The data is presented in Table 1 . In the thermal decomposition studies, a general pattern of uncoordinated chloride, coordinated chloride and water, ligand then finally gave the respective oxides at higher temperature.

\section{$U V$-Visible and magnetic susceptibility measurements}

The electronic spectrum of the copper complex exhibits bands at $25974 \mathrm{~cm}^{-1}$ and $15873 \mathrm{~cm}^{-1}$ which can be assigned to $2 \mathrm{~B} 1 \mathrm{~g} \rightarrow 2 \mathrm{~A} 1$ and $2 \mathrm{~B} 1 \mathrm{~g} \rightarrow 2 \mathrm{E} 1 \mathrm{~g}$ transitions. These transitions, as well as the measured value of the magnetic moment ( $\mu$ eff $=1.89 \mu \mathrm{B}$ ) suggest a squareplanar stereochemistry of the compound. The visible electronic absorption spectrum of the Cobalt(II) complex is dominated by the highest energy 4A2 $\rightarrow 4 \mathrm{~T} 1$ (P) transition, which is a typical one for tetrahedral $\mathrm{Co}(\mathrm{II})$ complexes. The magnetic moment value $(4.56 \mu \mathrm{B})$ and the light brown color of the Cobalt(II) complex, also suggest tetrahedral stereochemistry. The electronic spectrum of the nickel complex shows the two bands at $27397 \mathrm{~cm}^{-1}$ and $14925 \mathrm{~cm}^{-1}$ 
which are attributed to $1 \mathrm{~A} 1 \mathrm{~g} \rightarrow 1 \mathrm{~A} 2 \mathrm{~g}$ and $1 \mathrm{~A} 1 \mathrm{~g} \rightarrow 1 \mathrm{~B} 2 \mathrm{~g}$ transitions. These transitions, as well as the measured value of the magnetic moment $(3.66 \mu \mathrm{B})$ suggest a square-planar stereochemistry of the compound. Since the zinc ion has $\mathrm{d}^{10}$ configuration, the absorption at $28011 \mathrm{~cm}^{-1}$ could be assigned to a charge transfer transition. However, taking into account the spectrum and the configuration of the Zinc(II) ion, a tetrahedral geometry could be assumed for its complex ${ }^{13-15}$.

Table 1. Thermogravimetric analysis of the complexes

\begin{tabular}{lccclc}
\hline \multicolumn{1}{c}{ Compound } & Stage & $\begin{array}{c}\text { Temp } \\
{ }^{0} \mathrm{C}\end{array}$ & $\begin{array}{c}\text { Weight Loss, \% } \\
\text { Calculated/Found }\end{array}$ & \multicolumn{1}{c}{ Species Lost } & Residue \\
\hline$\left[\mathrm{CuLCl} . \mathrm{H}_{2} \mathrm{O}\right] \mathrm{Cl}$ & 1 & 100 & $15.17 / 15.03$ & Uncoordinated $\mathrm{Cl}$ & $\mathrm{CuO}$ \\
& 2 & 210 & $11.43 / 11.34$ & Coordinated & \\
& 3 & 320 & $70.84 / 70.27$ & Cl+ $\mathrm{H}_{2} \mathrm{O}$ Ligand & \\
{$\left[\mathrm{Co} \mathrm{LCl}_{2}\right]$} & 1 & 100 & $15.94 / 15.85$ & Coordinated $\mathrm{Cl}$ & $\mathrm{Co}_{2} \mathrm{O}_{3}$ \\
& 2 & 300 & $70.72 / 70.34$ & Ligand & \\
{$\left[\mathrm{Ni} \mathrm{LCl} . \mathrm{H}_{2} \mathrm{O}\right] \mathrm{Cl}$} & 1 & 100 & $7.66 / 7.59$ & Uncoordinated $\mathrm{Cl}$ & $\mathrm{NiO}$ \\
& 2 & 210 & $11.55 / 11.46$ & Coordinated & \\
& 3 & 330 & $68.11 / 67.57$ & Cl+ $\mathrm{H}_{2} \mathrm{O}$ Ligand & \\
{$\left[\mathrm{Zn} \mathrm{LCl}_{2}\right]$} & 1 & 100 & $15.71 / 15.60$ & Coordinated Cl & $\mathrm{ZnO}$ \\
& 2 & 310 & $69.82 / 69.14$ & Ligand & \\
\hline
\end{tabular}

\section{Biological activities}

\section{Antibacterial activity}

In view of their potent biological activity, the ligand and their metal complexes under present investigations were tested against five bacteria viz., Staphylococcus aureus and Bacillus subtilis which are representative type of gram positive bacterial groups and Escherichia coli, Pseudomonas aeruginosa and Salmonella Typhi which are representative type of gram negative bacterial groups. These bacterial strains are chosen as they are potential pathogens of human beings. The biological screening was conducted by disc method $^{5,15}$. The enhancement in the activity can be explained on the basis of chelation theory and the results obtained are presented in Table 2. The ligand and its metal complexes exhibit highly active at higher concentration.

Table 2. Antibacterial activity of the ligand and its complexes

\begin{tabular}{ccccccccccc}
\hline Compound & 50 & 100 & 150 & 200 & 250 & 300 & 350 & 400 & 450 & 500 \\
\hline $\mathrm{a}, \mathrm{b}, \mathrm{c}, \mathrm{d}, \mathrm{e} \downarrow$ & - & - & - & + & ++ & ++ & ++ & ++ & ++ & +++ \\
& - & - & + & + & + & ++ & ++ & ++ & ++ & +++ \\
$\mathrm{C}_{15} \mathrm{H}_{10} \mathrm{~N}_{3} \mathrm{O}_{3} \mathrm{Cl}(\mathrm{L})$ & + & + & + & + & + & + & ++ & ++ & ++ & +++ \\
& - & - & + & + & + & + & ++ & ++ & ++ & +++ \\
& - & - & + & + & + & + & ++ & ++ & ++ & +++ \\
\hline & + & + & + & ++ & ++ & ++ & ++ & ++ & +++ & +++ \\
& + & + & + & ++ & ++ & ++ & ++ & ++ & +++ & +++ \\
{$\left[\mathrm{CuLClH}_{2} \mathrm{O}\right] \mathrm{Cl}$} & + & + & + & ++ & ++ & ++ & ++ & ++ & +++ & +++ \\
& + & + & + & ++ & ++ & ++ & ++ & ++ & +++ & +++ \\
& + & + & + & ++ & ++ & ++ & ++ & ++ & +++ & +++ \\
\hline & + & + & + & ++ & ++ & ++ & ++ & ++ & +++ & +++ \\
& + & + & + & ++ & ++ & ++ & ++ & ++ & +++ & +++ \\
& + & + & + & ++ & ++ & ++ & ++ & ++ & +++ & +++ \\
& + & + & + & + & + & ++ & ++ & ++ & +++ & +++ \\
& + & + & + & + & ++ & ++ & ++ & ++ & +++ & +++ \\
\hline $\left.\mathrm{Co} \mathrm{LCl}_{2}\right]$ & & & & & & & & & & Contd $\ldots$
\end{tabular}




\begin{tabular}{|c|c|c|c|c|c|c|c|c|c|c|}
\hline \multirow{5}{*}[\mathrm{Ni}\mathrm{LClH}_{2}\mathrm{O}]{$\mathrm{Cl}$} & + & + & + & ++ & ++ & ++ & ++ & ++ & +++ & +++ \\
\hline & + & + & + & + & + & ++ & ++ & ++ & +++ & +++ \\
\hline & - & + & + & + & ++ & ++ & ++ & ++ & +++ & +++ \\
\hline & + & + & + & ++ & ++ & ++ & ++ & ++ & +++ & +++ \\
\hline & + & + & + & + & + & ++ & ++ & ++ & +++ & +++ \\
\hline \multirow{5}{*}[\mathrm{Zn}\mathrm{LCl}\mathrm{LC}_{2}]{} & + & + & + & + & ++ & ++ & ++ & +++ & +++ & +++ \\
\hline & + & + & + & ++ & ++ & ++ & ++ & ++ & +++ & +++ \\
\hline & - & + & + & ++ & ++ & ++ & ++ & ++ & +++ & +++ \\
\hline & + & + & + & ++ & ++ & ++ & ++ & ++ & +++ & +++ \\
\hline & + & + & + & + & ++ & ++ & ++ & ++ & +++ & +++ \\
\hline $\begin{array}{c}\text { Negative } \\
\text { control(DMF) }\end{array}$ & \multicolumn{10}{|c|}{ Nil } \\
\hline $\begin{array}{c}\text { Standard(mm) } \\
\text { Positive control }\end{array}$ & \multicolumn{10}{|c|}{$a=25, b=26, c=22, d=29, e=27$} \\
\hline
\end{tabular}

a: Escherichia coli , b: S. aureus, c: Bacillus subtilis, d: S. typhi, e: Pseudomonas aeruginosa $(\mu g / m L)$, DMF(control): Nil, No effect up to 24 hours

- : Inactive Less than $10 \mathrm{~mm},+$ : Weakly active between 10-14 mm, ++: Moderately active between $15-17 \mathrm{~mm},+++$ : Highly active above $18 \mathrm{~mm}$

\section{Antifungal activity}

The antifungal activity of the ligand and its metal complexes were tested against fungi Aspergillus niger, Aspergillus flavous and Candida albicans and the results obtained are presented in Table 3. The ligand and its metal complexes exhibit highly active at higher concentration.

Table 3. Anti fungal activity measurements of the ligand and its complexes

\begin{tabular}{|c|c|c|c|c|c|c|c|c|c|c|}
\hline Compound & 50 & 100 & 150 & 200 & 250 & 300 & 350 & 400 & 450 & 500 \\
\hline \multirow{3}{*}{$\mathrm{C}_{15} \mathrm{H}_{10} \mathrm{~N}_{4} \mathrm{O}_{5}(\mathrm{~L}, \mathrm{~L})$} & + & + & + & + & ++ & ++ & ++ & ++ & ++ & ++ \\
\hline & + & + & + & + & ++ & ++ & ++ & ++ & ++ & ++ \\
\hline & + & + & + & + & ++ & ++ & ++ & ++ & ++ & ++ \\
\hline \multirow{3}{*}[\mathrm{CuLClH}_{2}\mathrm{O}]{$\mathrm{Cl}$} & - & + & + & ++ & ++ & ++ & +++ & +++ & +++ & +++ \\
\hline & - & + & + & ++ & ++ & ++ & +++ & +++ & +++ & +++ \\
\hline & - & + & + & ++ & ++ & ++ & +++ & +++ & +++ & +++ \\
\hline \multirow{3}{*}[\mathrm{Co}\mathrm{LCl}_{2}]{} & - & + & + & ++ & ++ & ++ & +++ & +++ & +++ & +++ \\
\hline & - & + & + & ++ & ++ & ++ & +++ & +++ & +++ & +++ \\
\hline & - & + & + & ++ & ++ & ++ & +++ & +++ & +++ & +++ \\
\hline \multirow{3}{*}[\mathrm{Ni}\mathrm{LClH}_{2}\mathrm{O}]{$\mathrm{Cl}$} & - & + & + & ++ & ++ & ++ & +++ & +++ & +++ & +++ \\
\hline & - & + & + & ++ & ++ & ++ & +++ & +++ & +++ & +++ \\
\hline & - & + & + & ++ & ++ & ++ & +++ & +++ & +++ & +++ \\
\hline \multirow{3}{*}[\mathrm{Zn}\mathrm{LCl}\mathrm{LC}_{2}]{} & - & + & + & ++ & ++ & ++ & +++ & +++ & +++ & +++ \\
\hline & - & + & + & ++ & ++ & ++ & +++ & +++ & +++ & +++ \\
\hline & - & + & + & ++ & ++ & ++ & +++ & +++ & +++ & +++ \\
\hline $\begin{array}{c}\text { Negative } \\
\text { Control(DMF) }\end{array}$ & \multicolumn{10}{|c|}{ Nil } \\
\hline $\begin{array}{c}\text { Standard(mm) } \\
\text { Positive control }\end{array}$ & \multicolumn{10}{|c|}{$a=23, b=21, c=25$} \\
\hline
\end{tabular}

a:Aspergillus niger, b:Aspergillus flavus, c: Candida Albicans ( $\mu \mathrm{g} / \mathrm{ml}), \mathrm{DMF}(\mathrm{control}): \mathrm{Nil}$,

No effect up to 24 hours

$-:$ Inactive less than $10 \mathrm{~mm},+:$ Weakly active between 10-14 mm, ++: Moderately active between $15-$

$17 \mathrm{~mm},+++$ : Highly active above $18 \mathrm{~mm}$ 


\section{Conclusion}

The Schiff base ligand acts as bidentate monobasic with azomethine nitrogen and negatively charged oxygen atom as a donors. The probable geometry of structure for the complexes of $\mathrm{Co} \& \mathrm{Zn}$ would be tetrahedral and $\mathrm{Cu} \& \mathrm{Ni}$ would be square planar (Figure $2 \& 3$ ) respectively. The antibacterial and antifungal activity of ligand is greatly enhanced upon complexation with metal ions. Almost all complexes are highly active at higher concentration $(500 \mu \mathrm{g} / \mathrm{mL})$ except few they would moderately active.<smiles>Cc1cc([N+](=O)[O-])ccc1N(C(Cl)Cl)C1C(=O)Nc2ccc(Cl)cc21</smiles>

Figure 2. Tetrahedral geometry $\mathrm{M}=\mathrm{Co}$ and $\mathrm{Zn}$

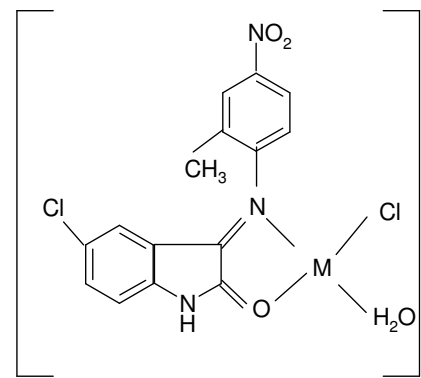

Figure 3. Square planar geometry $\mathrm{M}=\mathrm{Cu}$ and $\mathrm{Ni}$

\section{References}

1. Chohan Z H, Humayun Perveza, Rauf A, Khalid M Khan and Claudiu T Supuran, $J$ Enzyme Inhibition Med Chem., 2004, 19(5), 417-423.

2. Protivinsky R, Antibiot Chemother., 1971, 17, 101-121.

3. Joshi K C, Pathak V N and Jain S K, Pharmazie, 1980, 35, 677-679.

4. Shepherd R G, In: Burger, Medicinal Chemistry, Wiley, New York, 1970.

5. Atta-ur-Rahman, Iqbal Choudhary $\mathrm{M}$ and William $\mathrm{J}$ Thomsen, Bioassay Techniques for Drug Development, 2001.

6. Nakamoto K, Infrared Spectra of Inorganic and Coordination Compounds, $2^{\text {nd }}$ Ed., Wiley-Inter Science, 1970.

7. Nakamoto K, Infrared \& Raman Spectra of Inorganic \& Coordination Compounds, Part-B, $5^{\text {th }}$ Ed., Wiley Interscience Publication, 1997.

8. Shakir M, Nasman O S M and Varkey S P, Polyhedron, 1996, 15, 309-314; b) Shakir M, Islam K S, Mohamed A K, Shagufa M and Hasan S S, Transit Met Chem., 1999, 24(5), 577-580.

9. Chandra S and Kumar R, Trans Met Chem., 2004, 29(3), 269-275.

10. Simmons W W, The Sadtler Handbook of Proton NMR Spectra, Sadtler Research Laboratories, Inc., 1978.

11. Pasto D J, Organic Structure Determination, Prentice Hall International, London, 1969

12. Khan T A, Naseem S, Khan S N, Khan A U and Shakir M, Spectrochim Acta A, 2009, 73(4), 622-629.

13. Cotton F A and Wilkinson G, Advanced Inorganic Chemistry, Wiley-Interscience: New York, 1999.

14. Vogel A I, A Text Book of Quantitative Chemical Analysis, $5^{\text {th }}$ Ed., Longman, London, 1989.

15. Rama Krishna Reddy K and Mahendra K N, Russian J Inorg Chem., 2008, 53(6), 906-912. 